\title{
A study to Propose a Common Basis of Valuation for the Payment of Compensation for Property Rights Acquired by the State
}

\author{
L.H. Lickson
}




\section{A study to Propose a Common Basis of Valuation for the Payment of Compensation for Property Rights Acquired by the State}

Dissertation Submitted to the University of Sri Jayewardenepura

As a Partial Fulfillment for the

Requirements of the Final Examination of the M.Sc. in Real Estate Management and Valuation Degree

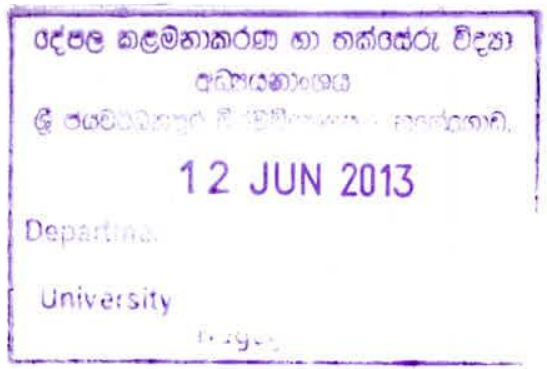

Full Name : LokuHennadigeLickson

Examination No : REMV/49

Registration No : GS/M.Sc./REMV/3401/08

Department : Department of Estate Management and Valuation

University : University of Sri Jayewardenepura

Date of Submission : 23.05.2013 


\title{
Student's Declaration
}

The work described in this dissertation was carried out under the supervision of Mr. H.M. Premathillake and any report on this has not been submitted in whole or in part to any university or any other institute for another degree /examination or any other purpose.

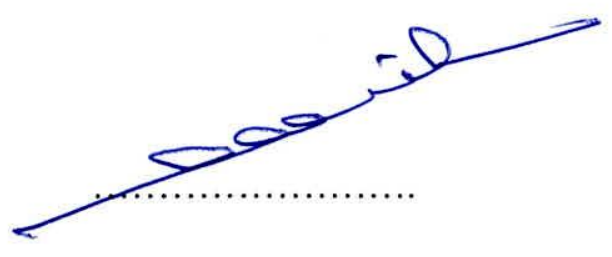

\author{
Full Name : LokuHennadigeLickson \\ Examination No : REMV/49 \\ Registration No : GS/M.Sc./REMV/3401/08 \\ Department : Department of Estate Management and Valuation \\ University : University of Sri Jayewardenepura \\ Date of Submission : 23.05.2013
}




\section{Supervisor's Declaration}

Hereby, I certify that Mr.L.H. Lickson (Registration No: GS/M.Sc./REMV/3401/08) duly completed the research titled "A Study to Propose a Common Basis of Valuation for the Payment of Compensation for Property Rights Acquired by the State" under my supervision and recommended to submit for the evaluation.
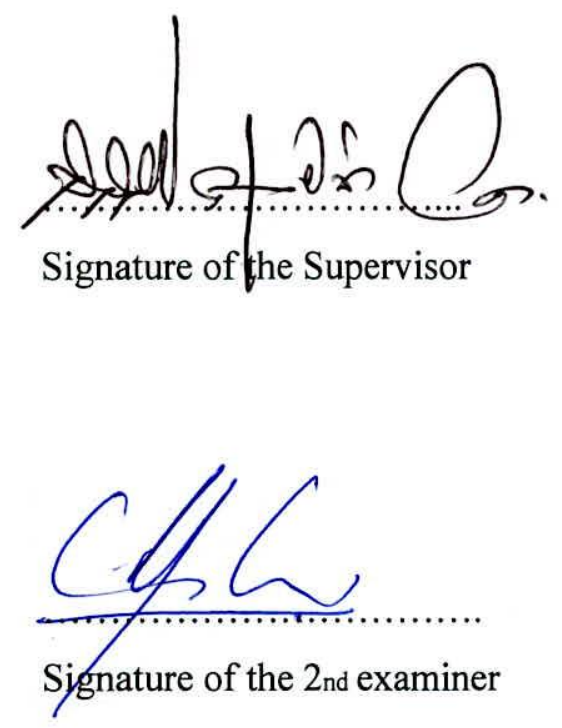

Signature and the official stamp of the Head 


\section{ACKNOWLEDGEMENT}

First, I would like to take my sincere thank to my Supervisor, Senior Lecturer, Mr. H.M. Premathilaka for necessary guidance towards to make this assignment successful. Then to the course coordinator Prof. R.G. Ariyawansa, Ms. Padma Weerakone, Ms. NishaniWickramaarachchi and Ms. JanakiEdirisinghe for enormous encouragement. Finally to the Department of Estate Management and Valuation of University of Sri Jayewardenepura, Authors and Publishers of books, journals, periodicals.

Also, I highly appreciated the help, assistance and courage given by Mr. W. H. T. Gunawardhene, all my family members and friends to make this research project submitted to Department Real Estate Management and Valuation of Faculty of Management - Post Graduate Studies of University of Sri Jayewardenepura as a partial fulfillment of the requirement of the Master of Science Programme2008/2010.

L.H. Lickson

May 23, 2013 


\begin{abstract}
Payment of compensation related to real estate acquisition of vesting. Basically the acquisition takes place when the government is looking to provide benefit to the public. Literature shows that there are different type's compensation methods in different countries. The main purpose of this study is to analyze existing system and introduce common basis of valuation for the payment of compensation for property rights vested by the State. Compensation receivers were analyzed whether they are satisfied for the payment received. This is a result of rapid increase of population, urbanization and transition. Looking at opportunities to maximize the public benefit government considers development opportunities Therefore it is essential to acquire lands for the development purpose protects.
\end{abstract}

There are many researchers have carried out in this thematic area. A two way approach involving a questionnaire and a structured interview was applied in this study. The questionnaire survey was focused to collected perspectives from claimants whose lands were acquiesced. Unit of analysis was beneficiaries. A sample of 100 beneficiaries was randomly selected covering from the areas of Badulla, Haliela, Haputale, Haldumulla, and Welimada were employed for this purpose. However, 92 completed questionnaires were received and the analysis was done based on those completed questionnaires using Statistical Package for Social Science (SPSS) computer software. 15 Structured interviews were held to ascertain their opinions on steps whichever necessary to identify the problems of compensation. Findings of the study indicate that there is a requirement of a common method of valuation for the payment of compensation. The key findings of this research will assist the policy makers to identify and introduce a suitable common method for the payment of compensation considering value to owner.

Key Words: Land Acquisition, Compensation, Common Compensation Method, Market Value. 


\section{Table of Contents}

Acknowledgement ................................... $i$

Abstract ............................................... $i i$

Table of Content ......................................... iii

List of table $\ldots \ldots \ldots \ldots \ldots \ldots \ldots \ldots \ldots \ldots \ldots \ldots \ldots \ldots \ldots$ vii

List of figure ...................................... viii

List of maps ........................................ ix

Contents Page

\section{CHAPTER ONE - Introduction}

1.1 Land Acquisition procedure in Sri Lanka 02

1.2 Back ground of the problem 03

1.3 Problem Statement 05

1.4 Objectives of the study 05

1.4.1 Specific Objectives 05

1.5 Limitation of the Research 05

1.6 Significance of the Research 06

1.7 Scope of the Study 06

1.8 Conceptual Framework 06

$\begin{array}{lll}1.9 & \text { Organization and previous of the Thesis } & 07\end{array}$

\section{CHAPTER TWO - Literature Review}

$\begin{array}{lll}2.1 & \text { Introduction } & 09\end{array}$

2.2 History of the Compulsory Purchase Laws in Sri Lanka 09

$\begin{array}{lll}2.3 & \text { What is compensation } & 10\end{array}$

$\begin{array}{lll}2.4 & \text { Compensation Definitions } & 10\end{array}$

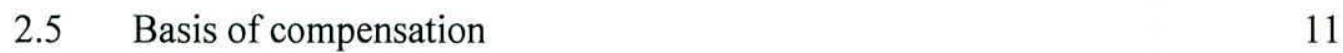

2.6 Land Acquisition Act No 9 of 1950 Sri Lanka 13

$\begin{array}{ll}\text { 2.6.1 Examples for Injurious affection } & 17\end{array}$

2.6.2 Urban Development Authority (UDA)Law, No 41 of $1978 \quad 21$

2.6.3 National Housing Development Authority (NHDA) Act, No 17 of 1979

2.6.4 Mahaweli Authority of Sri Lanka Act No 23 of 1979 
2.6.5 Walawe Land Act No 11 of 1958

2.6.6 Town Planning schemes

2.6.7 Colombo District (low Lying areas) reclamation and

Development board Act No 15 of 1968

2.6.8 Sri Lank state Trading corporation Act No 33 of 1970

2.6.9 Land reform (special Provision) Act, No 14 of 1986

2.6.10 under the Ceylon Petroleum Corporation Act, No 8 of 1961

2.6.11 Ceiling on Housing Property Law No 01 of 1973

2.6.12 Determination of compensation based on reasonable value 26

2.7 Land Acquisition and payment of compensation through case Laws 27

2.8 Literature from other scholars 30

2.9 Affected parties 35

2.10 Payment for Land Acquisition 36

2.11 Market Value 41

2.12 Valuation Methods 44

2.12.1 Comparable sales Approach $\quad 44$

2.12.2 Income capitalization Approach 44

2.12.3 Replacement cost Approach $\quad 45$

2.13 Valuation methods applied in Sri Lanka 45

2.13.1 Market Approach - Comparison Method 46

2.13.2 Income Approach - Investment Method 46

2.13.3 Developers Approach - Residual Method 46

2.13.4 Income Approach - Profit or Accounts Method 46

2.13.5 Cost approach - Contractor's Method $\quad 47$

\section{CHAPTER THREE - Research Area}

3.1 Land area and population $\quad 52$

3.2 Socio - Economic Infrastructure 52

3.3 Transportation $\quad 52$

3.4 Road area of the research focus 53

$\begin{array}{lll}3.5 & \text { Geography } & 72\end{array}$

$\begin{array}{lll}3.6 & \text { Demographics } & 72\end{array}$

$\begin{array}{lll}3.7 & \text { Research Methodology } & 72\end{array}$ 
3.7.1 Sample design 72

3.7.2 Secondary data collection $\quad 73$

$\begin{array}{lll}\text { 3.7.3 Primary data Collection } & 73\end{array}$

$\begin{array}{lll}3.7 .4 & \text { Methodology } & 73\end{array}$

\section{CHAPTER FOUR - Research Design}

$\begin{array}{lll}4.1 & \text { Population and Sample } & 75\end{array}$

4.2 Frequency of the Area Analysis 76

$\begin{array}{lll}4.3 & \text { Data collection } & 76\end{array}$

4.3.1 Primary Data Collection $\quad 76$

$\begin{array}{lll}\text { 4.3.2 Secondary Data Collection } & 77\end{array}$

$\begin{array}{lll}4.4 & \text { Data Analysing } & 78\end{array}$

\section{CHAPTER FIVE - Data Analysis}

$\begin{array}{lll}5.1 & \text { Operationalization of variables } & 79\end{array}$

5.1.1 Perspectives of compensation claimants $\quad 79$

5.1.2 Validation of measurement properties $\quad 79$

$\begin{array}{ll}\text { 5.1.3 Frequency of area Analysis } & 79\end{array}$

$\begin{array}{lll}5.1 .4 & \text { Normality Test } & 80\end{array}$

$\begin{array}{lll}\text { 5.1.5 Runs Test } & 81\end{array}$

$\begin{array}{lll}\text { 5.1.6 Kruskal - Wallis Test } & 81\end{array}$

5.1.7 The Kruskal - Wallis H Test 82

5.1.8 Decision under LABR 83

5.1.9 Compensation paid under three scenarios 90

- Compensation paid under Haldumulla DS division 90

- Compensation paid under Haputale DS division 92

- Compensation paid under Bdulla DS division 95

5.1.10 Dates of issuing of notices $\quad 100$

5.1.11 Analysis of question No $01 \quad 106$

$\begin{array}{ll}\text { 5.1.12 Analysis of question No } 02 & 107\end{array}$

$\begin{array}{ll}\text { 5.1.13 Analysis of question No } 03 & 107\end{array}$

$\begin{array}{ll}\text { 5.1.14 Analysis of question No } 04 & 108\end{array}$

$\begin{array}{ll}5.1 .15 \text { Analysis of question No } 05 & 108\end{array}$ 
5.1.16 Analysis of question No 06

5.1.17 Analysis of question No 07

5.1.18 Analysis of question No 08

5.1.19 Analysis of question No 09

5.1.20 Analysis of question No 10

5.1.21 Analysis of question No 11

5.1.22 Analysis of question No 12

5.1.23 Analysis of question No 13

5.1.24 Analysis of question No 14

5.1.25 Analysis of question No 15

5.1.26 Cross tabulation 113

5.1.27 Comparison of Payment of Compensation 115

5.2 Responding at the interviews conducted by the Author 117

\title{
CHAPTER SIX - Conclusion and Recommendations
}

$\begin{array}{lll}6.1 \text { Conclusion } & 120\end{array}$

6.1.1 Compare actual amount of compensation for each scenario 120

6.1.2 Claimants level of satisfaction 120

6.1.3 Delays of Payments of compensation 123

$\begin{array}{lll}6.2 & \text { Recommendation } & 125\end{array}$

\begin{abstract}
ANNEXES
Annexure 1 ....................... Reference

Annexure 2...................... Questionnaire

Annexure 3..................... Views of Professionals
\end{abstract}




\section{List of Tables}

Table3.1 Population details of Badulla Divisional Secretariat 56

Table3.2 Land used wise total extent of land acquired 56

$\begin{array}{lll}\text { Table3.3 Schedule of land sales as at 22.01.2010 } & 59\end{array}$

Table3.4 Population details of the Haldumulla DS division 62

Table3.5 Land used wise total extent of land acquired 63

Table3.6 Schedule of land sales as at 09.11.2007 65

Table3.7 Population details of the Haputale DS division 67

Table3.8 Land used wise total extent of land acquired 67

$\begin{array}{lll}\text { Table3.9 Schedule of land sales as at 20.07.2006 } & 70\end{array}$

Table4.1 Selected samples for each Divisional Secretariat 75

Table4.2 Frequency of the Area Analysis 76

$\begin{array}{lll}\text { Table5.1 Frequency of the area Analysis } & 79\end{array}$

$\begin{array}{lll}\text { Table5.2 Normality Test Table } & 80\end{array}$

$\begin{array}{lll}\text { Table5.3 Runs Test Table } & 81\end{array}$

Table5.4 Kruskal - Wallis Test table $\quad 82$

Table5.5 The Kruskal - Wallis H Test table 83

$\begin{array}{lll}\text { Table5.6 Separate decisions } & 84\end{array}$

Table5.7 Acquisition of Land s for Bandarawela town Development by UDA86

Table5.8 Compensation paid for the building subject to land slide $\quad 87$

Table5.9 Compensation paid Haldumulla DS division 90

Table5.10 Compensation paid Haputale DS division 92

Table5.11 Compensation paid Badulla DS division 95

Table5.12 Time duration for acquisition process in Badulla DS division area 100

Table5.13 Time duration for acquisition process in Haldummulla

DS division area 102

Table5.14 Time duration for acquisition process in Haputale DS division area 103 


\section{List of Figures}

Figure5.1 Cross tabulation Question No 3 and No $5 \quad 114$

Figure5.2 Average expected compensation as percentage 116

$\begin{array}{lll}\text { Figure5.3 Compensation demand and compensation payment } & 117\end{array}$ 


\section{List of Maps}

Map3.1 Three Divisional Secretariats in Badulla district 51

Map3.2 A4 road from Colombo to Badulla 54

Map3.3 Badulla District Administrative map 54

Map 3.4 Widening of Nuwara Eliya - Badulla road within Badulla

$\begin{array}{ll}\text { DSDivision area } & 58\end{array}$

Map3.5 Widening of Nuwara Eliya - Badulla road within Badulla DS

Division area - Land Sale $\quad 61$

Map3.6 Widening of Rathnapura - Beragala road within Haldumulla DS

Division area 64

Map3.7 Widening of Rathnapura - Beragala road within Haldumulla DS

Division area - Land sale 66

Map3.8 Widening of Diyathalawa - Rohentant road within Haputala DS

Division area $\quad 69$

Map3.9 Widening of Diyathalawa - Rohentant road within Haputala DS

$\begin{array}{ll}\text { Division area - Land sale } & 71\end{array}$ 


\section{CHAPTER ONE}

\section{INTRODUCTION}

Land which is a scarce natural resource plays a key role in development. Land is the foundation of all forms of human activity. It is the means of life without which human beings could never have existed and on which their continued existence and progress depend.

Also land is a factor of production. For any physical development to take place there should be land as the priority requirement. There are many proposed infrastructure development projects in the pipeline now in Sri Lanka. As a result the subject of Land Acquisition by the State has become important (Annual Report - CBSL, 2010).

Much of investors' incentive for the development maintenance and improvements of resources is rooted in the concept of property rights. At present with $84 \%$ of total the state dominates land ownership in Sri Lanka. Agricultural land accounts for approximately 2.79 million hectares or about $43 \%$ of total land mass, of this $53 \%$ is owned by the state, but farmed by private farmers under varying tenure agreements (World Bank, 1996).

But when and where land is necessary the government may not have lands needed for a particular public purpose. Hence the state has tools to acquire land for public purpose.

Land acquisition is the government tools to assemble land in solving the land supply problems for development projects. Hence land acquisition is a way out to solve problems with land ownership and land owners reluctance to offer their lands for development projects.

Land acquisition means the acquisition of ownership of private property by the state on behalf of the public through a specified legal process, for the use of the 
community. Sometimes, the expressions "expropriation" and "compulsory purchase" are also used to mean such transfer of ownership of a land.

A government cannot rely on land markets alone to ensure that land is acquired when and where it is needed. However, a number of countries require that the government should attempt to buy the required land in good faith before it uses its power of compulsory acquisition. Compulsory acquisition requires finding the balance between the public need for land on the one hand, and the provision of land tenure security and the protection of private property rights on the other hand.

There is a generally accepted principle that on such a transfer of ownership of land from private to public, fair and reasonable compensation should be paid by the state representing the community to the individual member of the community from whom the land is acquired. This principle of payment of just and fair compensation for compulsory acquisition is guaranteed in many countries by the constitution. However, this concept of payment of compensation is sometimes questioned on social grounds. It is argued that the land originally belonged to the community at large, and therefore, what is being achieved through compulsory acquisition is just an attempt to reach the status ante. The community is merely taking over what belonged to the community.

\subsection{Land Acquisition Procedure in Sri Lanka}

Ministry of Land

Section 2 (LA Act, Investigation for selecting land for public purpose rigid selection in case of Road Widening)

Section 4 (Notice of Intention of Acquisition and for objection)

Section $5 \searrow$ Declaration

Acquiring Officer - Sec 6 request Survey General for Acquisition Plans and sent to relevant authorities including Chief Valuer) 